\title{
Znáte schistocyty?
}

\section{prof. MUDr. Zdeněk Doležel, CSc. ${ }^{1}$, MUDr. Veronika Fiamoli, Ph.D. ${ }^{2}$, MUDr. Jan Papež' \\ 'Pediatrická klinika LF MU a FN Brno \\ ${ }^{2}$ Oddělení klinické hematologie FN Brno}

Klíčová slova: hemolytická anémie, schistocyty, morfologie erytrocytů.

Key words: hemolytic anemia, schistocytes, erythrocytes morphology.

Čtrnáctiměsíční batole bylo v domácích podmínkách přibližně týden léčeno symptomaticky pro akutní průjem. Stolice byla zpočátku kašovité konzistence, 7-8x/24 hod. Přibližně 36 hod před prijjetím k hospitalizaci se průjem změnil na hemoragický, u dítěte se objevilo občasné zvracení, bylo afebrilní a matka si všimla výrazně snižených porcí moči. Při príijetí k hospitalizaci byla dívka (tělesná hmotnost 11 kg, délka $78 \mathrm{~cm}$ ) při vědomí (Glasgow coma scale 15) nápadně bledá, na kǔži břicha měla četné petechie. Dítě mělo hypertenzi (TK 138/80 mmHg), tachykardii 150/min, počet dechů 35/min a prì $\mathrm{FiO}_{2} 21 \%$ byla saturace $95 \%$. Abnormální byly tyto laboratorní hodnoty: urea $40 \mathrm{mmol} / \mathrm{l}$, kreatinin

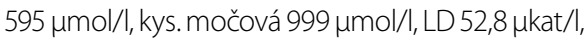
CRP $38 \mathrm{mg} /$, haptoglobin < 0,03 g/l; hemoglobin $57 \mathrm{~g} / \mathrm{l}$, hematokrit 0,16, leukocyty $24,3 \times 10^{9} / 1$ (v dif. rozpočtu bylo 7 tyčí), trombocyty $12 \times 10^{\%} / 1$. Analýza hemokoagulačních parametrů prokázala pouze zvýšení D-dimerů; prímý Coombsưv test byl negativní. Při mikroskopickém vyšetření nátěru z periferní krve dominoval nález vysokého počtu schistocytů (95/1000 erytrocytů; obrázky 1-3). Vyšetření moči - chemicky: bílkovina 2, krev 2, leukocyty 2, v sedimentu byla záplava erytrocytů, přes kterou se nepodařilo počet leukocytů presně určit. Ultrazvukové vyšetření zobrazilo zvětšené ledviny s výrazně hyperechogenní kưrou, korodřeňová diference byla místy setřelá. Anamnestické údaje a hodnoty laboratorních vyšetření umožnily prakticky inned určit diagnózu - Hemolytickouremický syndrom (HUS).

U dítěte byla krátce po prijietí zahájena kontinuální veno-venózní hemodiafiltrace (CVVHD-F),
Obr. 1. Schistocyty různé morfologie (šipky)

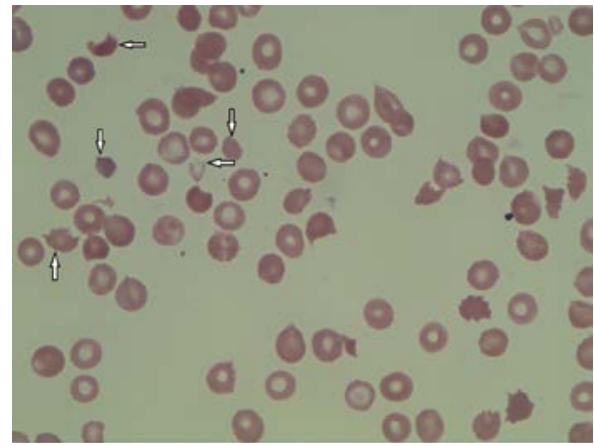

její délka byla celkem 68 hod. Batole bylo po celou dobu CVVHD-F stabilizované, diuréza se postupně zvyšovala a upravily se pozměněné laboratorní hodnoty, a také TK. V cíleně vyšetřených vzorcích stolice byl prokázán verocytogenní kmen E. coli O157. S odstupem bylo dítě v dobrém zdravotním stavu propuštěno domů a zůstává ve sledování nefrologické ambulance.

Schistocyty ( $z$ reckého slova schisto = rozdrcený/rozštěpený; SCH) jsou cirkulující fragmenty erytrocytů (Ery). Vznikají mechanickým poškozením membrány Ery fibrinovými vlákny na cévním endotelu, ale také při nadměrné turbulenci krve. SCH jsou vždy menší než intaktní Ery a chybí jim typické centrální projasnění. Při mikroskopickém vyšetření jsou za SCH považovány:

- a) malé fragmenty různého tvaru,

- b) helmovité Ery,

- c) keratocyty (tzv. buňky tvaru kočičí hlavy),

- d) mikrosférocyty.

Dosud chybí konsensus pro vyjádření horní meze $\mathrm{SCH}$. Obecně je prijjato, že počet $\mathrm{SCH}$ > 10/1000 Ery v nátěru periferní krve je výrazný
Obr. 2. Schistocyt tvaru kočičí hlavy (šipka)

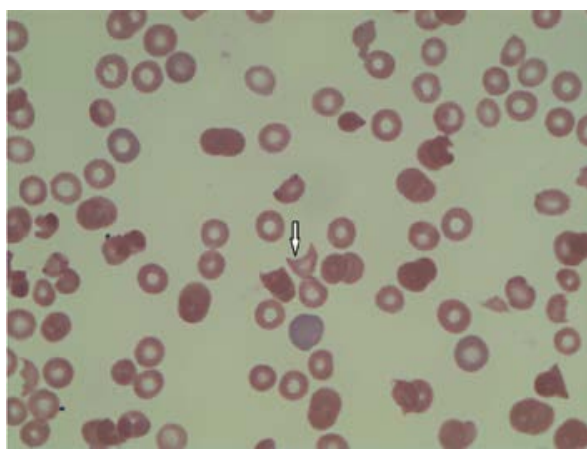

Obr. 3. Helmovité erytrocyty (šipky)

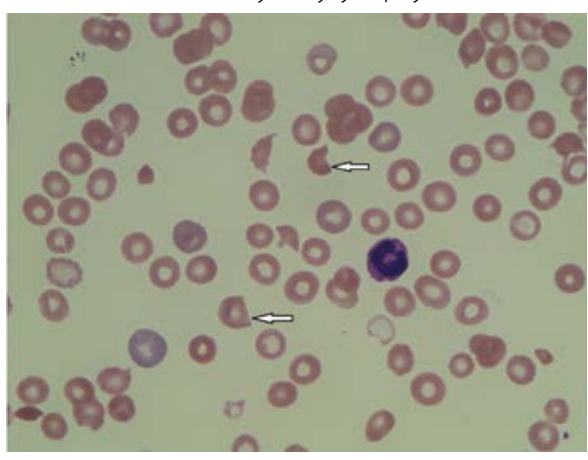

morfologický ukazatel trombotické mikroangiopatické anemie (TMA). TMA charakterizuje tetráda Coombs-negativní hemolytické anemie, trombocytopenie, zvýšení sérové koncentrace LD a snížená hladina haptoglobinu. Při podežrení na TMA je proto racionální nezapomenout na mikroskopické vyšetření nátěru periferní krve. Knejčastějším TMA dětského věku, která provází vzestup počtu SCH patří především HUS a trombotická trombocytopenická purpura. Zvýšený počet SCH bývá také u pacientů s uremií, se závažnou hypertenzí nebo u těžších chlopenních vad srdce. 